\title{
The Impact of Prison Rape on Public Health
}

\author{
M. Dyan McGuire
}

Saint Louis University

\begin{abstract}
One of the most significant threats to the health of incarcerated persons is prison rape. Through such acts, communicable diseases are spread and physical and mental injuries are inflicted. This article evaluates the evidence regarding the extent to which prison rape occurs in both men and women's correctional facilities in the United States. It also discusses how prison rape jeopardizes public health by exposing the community to disease, brutalized inmates who are likely to have become more violent as a result of their victimization, and the cancer of racism. Current efforts to deal with the prison rape problem, particularly the Prison Rape Elimination Act of 2003 are explored. Policy recommendations, including the adoption of “no-drop” policies for prosecutors' officers dealing with prison rape cases are proposed and discussed.
\end{abstract}

(C) 2005 Californian Journal of Health Promotion. All rights reserved.

Keywords: prison rape, Prison Rape Elimination Act, prison violence

\section{Introduction}

As is widely recognized, the prison population has been steadily increasing over the last several decades. According to the Bureau of Justice Statistics (BJS), by year-end 2003, state and federal prison authorities had 1,470,045 inmates under their jurisdiction (Harrison \& Beck, 2004). This reflects an increase in incarceration rate from 411 per 100,000 of the U.S. population in 1995 to 482 per 100,000 in 2003. Clearly, from a public health perspective, it is important to understand the health implications of the prison experience since it is such a widespread and growing phenomenon.

One of the health risks associated with imprisonment is nonconsensual sexualencounters. While it is widely known that rapes occur in prison, one of the biggest obstacles to dealing with the problem effectively is the difficulty in accurately quantifying the extent of the problem. Rape victims are notoriously reticent about their victimization. One major national report concluded that only about 16 percent of rape victims report their victimization (Kilpatrick, Edmunds, \& Seymour, 1992). A comparison of rape and sexual assault data from the Uniform Crime Report (UCR) and the National Crime Victimization Survey (NCVS) confirms that a substantial proportion of victims fail to report their victimization to the authorities. In 2003, according to the UCR, there were 93,433 forcible rapes while the NCVS estimates that there were more than twice that many rapes/sexual assaults in 2003 (Catalano, 2004; Federal Bureau of Investigation [FBI], 2005).

Often cited reasons for failure to report sexual victimization include shame, guilt, embarrassment, belief that it is a private matter or that the authorities will do nothing, and the desire to avoid the discomfort of reliving the experience through the process of prosecution. Evidence suggests that men are even less likely to report sexual victimization than women (Pino \& Meier, 1999). All of these "general" reasons for not reporting sexual victimization are applicable to prisoners (Robertson, 2003).

In addition to the normal reasons for not reporting, victims of sexual abuse in prison have additional reasons for remaining silent. Perhaps the most significant reason for not reporting an assault is that prisoners are at risk of potentially lethal reprisals if they break the prison code by snitching to the authorities (Kupers, 2001; Struckman-Johnson \& Struckman-Johnson, 
2000). Given our society's construction of gender and the perceived emasculating effects of being forced to submit to homosexual intercourse (Donaldson, 2001; O’Donnell, 2004; Robertson, 2003), the pressure to remain silent may well be even more acute for male victims. Acquiring the "punk" or "queer" label in a male prison frequently results in additional victimization, further motivating victims to conceal their victimization (Anonymous, 2001; Kupers, 2001; Robertson, 2003).

Perpetrators have obvious motives to conceal their crimes. Although the authorities are often ineffectual in their responses, being caught for raping another inmate can result in additional penal or administrative sanctions. Since the parties to a prison sexual assault all have motives to conceal the event, there is good reason to believe that prison rape is vastly underreported and the available data regarding sexual victimization in prison probably represents very conservative estimates of the actual occurrence of prison rape (Dumond, 1992; Struckman-Johnson \& StruckmanJohnson, 2000). This conclusion is strengthened by the fact that in one leading study only 29 percent of the inmates who admitted to researchers that they had been sexually victimized reported their victimization to the authorities (Struckman-Johnson, Rucker, Bumby, \& Donaldson, 1996).

Despite pressure to conceal victimization, the existing data suggests that male inmates are sexually assaulted by other inmates at an alarming rate. A study involving three Nebraska prisons found that 22 percent of the male inmates had been pressured or forced to have sexual contact with another inmate (StruckmanJohnson et al., 1996). More recent work involving seven correctional facilities in the Midwest reached similar conclusions finding that 21 percent of the male inmates had experienced at least one episode of pressured or forced sexual contact (Struckman-Johnson \& Struckman-Johnson, 2000). A third of those who admitted to a coercive sexual contact (i.e., seven percent of the sample) reported that they had actually been raped at their current facility, and in more than half of those cases, (i.e., four percent of the sample), those individuals reported they had been raped fairly recently (within the last 21/2 years) (Struckman-Johnson \& Struckman-Johnson, 2000). While their response rate was low (25 percent), these statistics nonetheless suggest a substantial problem.

The results of these self-report studies are consistent with the estimates of both prison employees and criminologists. In one study measuring prison guard's estimates of prison rape, officers estimated that about 18 percent of male inmates were raped while incarcerated (Eigenberg, 2000). Messerschmidt (2001) suggests that about 20 percent of the male inmates in the United States will be raped at some point during their incarceration.

Although a minority opinion, it should be noted that some experts believe that prison rape among male inmates is exaggerated and that most of the sexual contact among male inmates in prison is consensual (Saum, Suratt, Inciardi, \& Bennett 1995). Certainly the level of reported victimization would seem to support the contention that the vast majority of sex in prison is consensual. In one study nearly $3 / 4$ of the wardens surveyed (72 percent) reported that no inmate had reported being sexually assaulted in their institutions in the last 12 months (Hensley, Koscheski \& Tewksbury, 2003). Even some self-report studies indicate that the incidence of sexual assault is lower than the generally recognized level of one in five. For example, a recent study involving men incarcerated in Oklahoma indicates that while 14 percent of the sample was the target of unwelcome sexual attention, only a little over one percent of the sample was actually the victim of a sexual assault (Hensley, Tewksbury \& Castle, 2003).

While it has long been suspected that male inmates assault each other at high rates, until recently it has been assumed that guards rarely sexually assault male inmates. StruckmanJohnson and her colleagues, however, found evidence to the contrary where in their study, 18 percent of the incidents reported by male inmates were perpetrated by guards (StruckmanJohnson et al., 1996). Guards also contribute to 
the problem of prison rape even when they do not personally participate in assaulting inmates by being complicit in attacks committed by inmates (O’Donnell, 2004).

Contrary to the situation of male inmates, until fairly recently, it was assumed that there was very little or no sexual violence between female inmates - and female inmates were only at risk of sexual victimization by male guards. Recent research belies this assumption. The evidence suggests that women are, in fact, sexually assaulted by fellow inmates (see Easteal, 2001) and that serious injuries can be inflicted during such assaults (McGuire, 2005). There is also evidence that gang rapes occur in women's prisons (Alarid, 2000). One of the few large scale and comprehensive studies focusing on female inmates indicates that in three Midwestern prisons for women the sexual coercion rate varied from eight percent to 27 percent and that about half of these incidents were perpetrated by other inmates (StruckmanJohnson \& Struckman-Johnson, 2002).

In addition to same sex assaults by other female inmates, incarcerated women are also occasionally subjected to abuse by male inmates. While such assaults are more likely to occur in county jails that mix male and female prisoners, they can also occur in prisons where male and female inmates are supposed to be kept separate from one another. For example, where male and female prisons share the same compound, male inmates are sometimes given access to female inmates through inadvertence, as when a guard negligently abandons his post thereby allowing male prisoners access to female prisoners (Latour, 2001). Even more shocking than gross negligence, are cases where guards orchestrate assaults by "selling" female inmates to male inmates (see Day, 1998; Springfield, 2000).

Unlike inmate on inmate sexual abuse, the sexual abuse of female inmates at the hands of male correctional officers has long been recognized as a problem (Day, 1998; Dobash, Dobash \& Gutteridge, 1986; Smith 2001). However, efforts to limit male correctional officers' access to imprisoned women have not been successful and the sexual abuse of female inmates by male guards persists despite widespread recognition of the problem (Bell et al., 1999; Chesney-Lind \& Pollock, 1995). In the early 1990s, evidence of a coercive sex ring involving as many as half the guards and a quarter of the inmates was uncovered at Hawaii's prison for women (Meyer, 1992). Similar evidence of widespread abuse in Georgia's Milledgeville State Prison came to light after women filed suit (Smith, 2001). In the Georgia case, 17 staff members were ultimately indicted for sexually abusing female inmates (Smith, 2001). Anecdotal accounts of "rogue" officers sexually violating the inmates in their charge abound in the media (see Cooper, 2004).

Sexual contact between prison employees and female inmates has long been against prison policy. Yet, until relatively recently, the sexual abuse of prisoners was not specifically criminalized in most jurisdictions. Today, all but a handful of states have laws that make sexual contact between correctional staff and inmates a criminal offense (Smith, 2001). And, the federal courts have recognized that sex between an inmate and a guard is a per se violation of the Eighth Amendment irrespective of consent (see Carrigan $v$ Davis). Thus, engaging in sex with an inmate potentially exposes a prison employee to administrative, criminal and civil sanctions, even if force is not used. As a result, such events usually occur surreptitiously.

To make matters worse, in a dispute with staff, female inmates are frequently disbelieved. All of these circumstances make quantifying the extent of the problem of guard on inmate abuse extremely difficult. As previously indicated, women at three Midwestern prisons reported being the victims of sexual coercion at rates that varied between eight and 27 percent, about 45 percent of the reported incidents were perpetrated by staff (Struckman-Johnson \& Struckman-Johnson, 2002). Evidence of an extensive problem of guard-on-inmate abuse was also gathered by Calhoun and Coleman (2002) -who found that inmates estimate that about 20 percent of correctional officers have sexual contact with inmates. 


\section{Health Implications for the Victims of Prison Sexual Assaults}

There are serious health implications for inmates from instances of nonconsensual sexual contact. These implications are all the more alarming given that after an initial assault, the victim is often labeled a "punk," reduced to the level of sexual slave and then repeatedly brutalized and even "lent out" for purposes of sexual assault to other prisoners (Donaldson, 2001; O’Donnell, 2004; Robertson, 2003). One study found that the average prison rape victim experienced nine assaults (Struckman-Johnson et al., 1996). There is also evidence that a significant proportion of sexual assaults in prison are gang rapes (Robertson 2003; Struckman-Johnson, et al., 1996). The multiple-perpetrator and/or serial and on-going nature of prison sexual assaults magnifies' the likelihood that the victim will suffer serious detrimental effects from the assaults (see Anonymous, 2001).

Prisoners, as a class, are not a healthy group. According to the BJS, in 2002, the overall rate of confirmed AIDS cases in the prison population (0.48 percent) was nearly $3^{1 / 2}$ times the rate in the U.S. general population $(0.14$ percent). Some experts place the actual infection rate in prison for AIDS/HIV at 10 times the general population (Polych \& Sabo, 2001). Prisoners are also frequently infected with syphilis as well (Goldstein, 2003). The prevalence of latent tuberculosis infection (LTBI) among prison inmates is four times higher than the prevalence in the general population (Ashkin et al., 2005). The rate of hepatitis infection among prisoners is similarly alarmingly high (Rohde, 2001). Involvement in consensual sex, rape, or exposure to blood can increase the transmission of Hepatitis B - which claims 5,000 lives a year (Rohde, 2001) - or Hepatitis C. With Hepatitis C, the rate of infection among the general population is approximately 1.8 percent while studies of state prison populations indicates that 14 percent of New York State's prisoners are infected, 28 percent of Texas's prisoners are infected, and 33 percent of California's inmates have the disease (Rohde, 2001).
Sexually transmitted diseases such as HIV, syphilis, gonorrhea, herpes, and Hepatitis B as well as other communicable diseases can all be spread through sexual contact. The high incidence of infection among prisoners combined with the unavailability of condoms in prison make even consensual sex behind bars a risky proposition in terms of disease transmission. When the violence of a forcible assault is added, the risk of infection becomes even more pronounced and the possibility of "safe sex" even more illusory. After all, the circumstances surrounding a typical sexual assault are hardly conducive to the deliberate use of a prophylactic or other protective measures. Victims and even perpetrators of sexual assaults between prisoners thus face a substantial chance of contracting a debilitating or even fatal disease (Dumond, 1992; Vetstein, 1997).

In addition, where threats or fear are insufficient to induce submission, victims may be seriously beaten, suffering concussions, broken bones, lacerations, and other physical injuries -not to mention genital injuries associated with forced sexual penetration. Moreover, sexual assaults can cause a climate of violence that goes far beyond an actual attack. Research indicates that fear of sexual assault in prison generally increases violence among inmates (Lockwood, 1980; Struckman-Johnson \& StruckmanJohnson, 2000). Individuals who believe that they may be potential victims may lash out preemptively at perceived perpetrators or may engage in general acts of violence to establish a tough reputation to protect themselves from attack (Dumond, 1992; McGuire, 2005; Robertson, 2003).

It is well-known that in addition to physical trauma, victims of sexual assault endure significant mental and emotional anguish as well. Victims of prison sexual assault frequently suffer from rape trauma syndrome or posttraumatic stress disorder (Dumond \& Dumond, 2002; Robertson, 2003). There is also some evidence that being forced into homosexual relationships while in prison can so traumatize a victim that it redefines his sexual orientation precluding resumption of his pre-prison heterosexual lifestyle (Sagarin, 1976). While 
there is nothing socially or personally deleterious about consensually engaging in homosexuality, the fact that prison sexual assaults seem to precipitate such a fundamental life change certainly suggests that these are very traumatic events. There is also evidence that some victims of prison sexual assault turn to substance abuse and even suicide to cope with the mental and emotion pain of such victimization (Dumond, 1992).

\section{Health Implications for the Community of Prison Sexual Assaults}

While the human suffering inflicted upon the victims themselves is reason enough for our society to take strong action to reduce prison rape, the reality is that prison rape also has a very real and very dangerous direct impact on the public far beyond the prison walls. Prison is not a permanent situation for most inmates. The vast majority of prisoners will eventually be released back into society (Travis, 2005). Sharp increases in incarceration rates have resulted in a corresponding rise in the number of inmates released back into society. According to the BJS (2004), in 2001, 592,000 offenders were released from State prison - a 46 percent increase over the 405,400 offenders who were released in 1990. At least 95 percent of prisoners currently being held by state authorities will eventually be released back to society (BJS, 2004). Many of them will leave prison infected with diseases, thus posing a significant public health risk of spreading these diseases to the general population (Ashkin, Malecki, \& Thomas, 2005; Goldstein, 2003; Rohde, 2001).

Criminologists have long maintained that men who are victimized by sexual assault in prison often leave prison far more violent and antisocial than when they went inside (Dumond, 1992, Gilligan, 2000). Little work has been done on the brutalization effect of prison rape on women, although there is reason to believe it makes women violent and dangerous as well (Bell, et al., 1999). The danger this poses to society was expressly recognized by Congress in enacting the Prison Rape Elimination Act (PREA) of 2003 which specifically found that "prison rape endangers the public safety by making brutalized inmates more likely to commit crimes when they are released" (PREA, 2003).

The brutalization effect associated with prison rape may be particularly significant because the targets of most of these prison sexual assaults are young, nonviolent, first-time offenders for whom rehabilitation probably holds out the most hope (Dumond, 1992; PREA, 2003). By brutalizing the "best" or "least dangerous" prisoners, prison rape may seriously undermine the extent to which prison can have a reforming impact and assures that even those who arrive at prison uncommitted to violence and aggression do not leave that way. As a result, the individuals released from prison are likely to be even more inclined to violently victimize other people than before they were incarcerated. There is also some evidence that perpetrators of prison sexual violence may be sexually violent with their female partners post-release (Sagarin, 1976). The public health costs of violence, both domestic and otherwise, are well-documented and extensive.

Prison rape victims not only threaten public health and safety upon their reintroduction to the community, they may also threaten the social fabric of the community as well. Racism is among the most toxic of social evils. The evidence seems to suggest that much of the sexual violence in prison has a racial component and involves black offenders and white victims (Knowles, 1999). Some scholars suggest that black on white prison rape is a legacy of slavery, the lynch mob and the continuing oppression of blacks in American society (O'Donnell, 2004). While perpetrators of racialized sexual violence may view the attacks in terms of just deserts or simply "getting even," the victims surely do not. In fact, it would actually be very surprising if white victims of racialized sexual violence in prison did not develop attitudes of fear, hatred and loathing towards their assailants that could quite easily translate into racist attitudes toward black people in general. Perhaps others who are merely aware of the assaults may also develop racist beliefs. The formation and hardening of racist attitudes in prison eventually infects the community when these inmates are released 
(see, PREA, 2003). Thus, allowing prison rape to go unchecked not only endangers public health but it also endangers the social welfare by providing a mechanism through which racist hatred in the community can be fueled and strengthened.

\section{Current Efforts to Deal With the Problem}

On September 4, 2003, President Bush signed into the law the Prison Rape Elimination Act of 2003. This Act explicitly recognizes that prison rape is a major problem with serious public health ramifications (see PREA, 2003 sections 15601 - 15609). The Act establishes a National Prison Rape Elimination Commission (hereafter Commission) to carry out a comprehensive legal and factual study of the penalogical, physical, mental, social, and economic impacts of prison rape on Federal, State and local governments and communities, social institutions and individuals (PREA, 2003).

The Commission is further charged with recommending national standards based upon the results of their study. These national standards are to reflect the "best practices" with regard to numerous facets of the prison rape problem including classification and assignment of prisoners, investigation and resolution of rape complaints, preserving evidence and providing acute and long term medical care to treat injuries, minimization of disease transmission, and minimization of psychological/emotional damage (PREA, 2003). The Commission is also directed to provide recommendations for national standards regarding staff training, comprehensive investigation of allegations of staff misconduct, the creation of confidential means of reporting rape victimization, and methods of protecting complainants (PREA, 2003).

Within a year of receiving the Commission's recommendations, the Attorney General is directed to publish a final rule adopting national standards for the detection, prevention, reduction, and punishment of prison rape (PREA, 2003). Facilities within the Federal Bureau of Prisons will be obliged to comply with these standards by the terms of the Act (see PREA, 2003 section 15607 (b)). State correctional systems will be induced to comply because failure to do so will result in forfeiture of a proportion of the money they would otherwise receive from the federal government for prison purposes. Accrediting organizations are also required to adopt the national standards promulgated by the Attorney General as their accrediting minimum in order to remain eligible for federal grants. Therefore, state and local facilities will have to meet the national standards in order to keep both all of their federal money and their accreditation.

In addition to the massive "one-time" undertaking of the Commission, the Act also provides for on-going monitoring of the problem by charging BJS with responsibility for carry out a yearly, comprehensive statistical review and analysis of the incidence and effects of prison rape. State and federal prison administrators are required to participate and to provide access to their inmates as requested by the BJS. This review and analysis should help overcome one of the principle problems associated with dealing with the prison rape problem, namely, the problem of accurately quantifying the extent of the problem.

Recognizing that no reliable collection methodology for measuring prison rape currently exists, BJS has responded to its charge of conducting annual comprehensive statistical reviews by investing considerable resources in developing and testing the use of audio computer-assisted self-interview (CASI), which involves inmates listening to audio instructions via headphones and responding using a computer touch screen (BJS, 2004). It is anticipated that removing the presence of a human interviewer will increase inmate willingness to report sensitive information (BJS, 2004). Unlike traditional self-administered survey techniques, however, people who are illiterate can participate and the conditions under which the inmates complete the questionnaires can be controlled (BJS, 2004). In recognition that despite the improvements promised by audio-CASI, some inmates may still fear that revealing their victimization while in prison may subject them to retribution or further victimization. BJS will also survey recently 
released inmates to determine whether incarceration status influences reported victimization rates (BJS, 2004).

In addition to more accurately quantifying the problem of prison rape, the annual BJS statistical review will also help administrators craft targeted policies by identifying the common characteristics of both victims and perpetrators of prison rape (see PREA, 2003 section 15603(a)(1)(A)). Perhaps more importantly, the Act may get apathetic administrators to quit ignoring the problem of prison rape. The Act identifies among its purposes the establishment of a zero-tolerance standard for prison rape. It also directs that the prevention of prison rape is now a top priority in every prison system and administrators who fail to detect, prevent, reduce and punish prison rape should be held accountable (See PREA, 2003 sections 15602[2] and 15602[3]). By requiring the BJS to identify prisons and prison systems with high incidences of prison rape and then tying compliance to money, as explained above, even apathetic administrators will have a tangible incentive to work to reduce prison rape.

\section{Additional Reforms That May Help}

While these initial steps are promising, more needs to be done. Sexual coercion rates appear to be positively related to overcrowding and understaffing (Struckman-Johnson \& Struckman-Johnson, 2000). In a world of fiscal constraints and diminishing resources, there is every reason to believe that the problem of prison sexual assault will continue to grow. It should be noted that these proposed reforms are specifically directed toward the problem of sexual assault in prison, as distinct from other correctional settings. The differences between jails and prisons, including the comparatively high turn-over and relative inability to segregate inmates based upon sex, age and prior offending behavior (especially in smaller jails) make the problem of sexual assault in jail such a sufficiently unique phenomenon that it warrants separate assessment and different ameliorative measures.

While sexual assault in prison is a criminal offense and most correctional institutions have procedures for referring such cases to the local prosecutor's office, they usually utilize internal disciplinary mechanisms rather than formal prosecution (Abraham, 2001). Even when referrals are made, prosecutors are often reluctant to pursue the case and, as a result, few prison rape cases ever actually get prosecuted (Abraham, 2001; Dumond, 1992; Robertson, 2003). One of the explanations often used by prosecutors to justify ignoring prison violence in preference to crimes that occur on the outside is lack of resources. Under the Prison Rape Elimination Act, however, Congress has provided substantial pools of money to help train and assist prosecutors in investigating and punishing prison rape, making it possible for under-resourced prosecutors' offices to access external monies to help them pursue prison rape cases effectively and efficiently (see PREA, 2003 sections 15604; 15605). Thus, now is a particularly opportune time for prosecutors' offices to develop new policies aimed at vigorously and consistently pursuing those who commit sex crimes while they are incarcerated.

One of the chief problems prosecutors must frequently overcome in making a prison rape case is the lack of a victim's cooperation. Because of prison subcultural norms against "ratting," cooperating victims are often placed in physical peril if they pursue charges against their attacker (Dumond, 1992). In many ways, this presents a situation similar to the problems confronted when addressing domestic violence. Frequently battered women refuse to cooperate with prosecutors because they fear reprisal by their partners if they pursue legal redress. As a result, a number of prosecutors' offices nationwide have adopted "no drop" and "victimless prosecution" policies whereby the prosecutors' office does not drop domestic violence cases and will pursue them even if the victim expresses a preference for dropping the case and refuses to testify. These cases are then proved using officer testimony, 911 calls, hospital records and the like.

A similar policy should be adopted with prison sexual assault cases. Offenders should be treated as serious criminals, immediately placed in solitary confinement pending trial once 
probable cause is established, and the case automatically referred to the prosecutor. The prosecutors' office should then pursue charges whether the victim desires prosecution or not. Victimless prosecution may take more "leg work" than conventional prosecutions because it may be necessary to comb institutional and hospital records for evidence. Also, the investigation necessary to locate other witnesses will be time consuming, although such efforts should not be dismissed as futile. While it is true that many assaults will be carried on in secret without the presence of witnesses, witnesses nonetheless sometimes can be found. Saum and her colleagues in interviewing inmates in Delaware found that four percent of their sample admitted that they had actually seen at least one rape occur in the preceding 12 months (Saum et al., 1995).

Getting witnesses to talk will be difficult. As with victims, witnesses face risks associated with "ratting," but in some instances removing the perpetrator from the facility or inducements like transfers or "good time" credit for cooperating may be sufficient to overcome a witness's reticence. A requirement that the complaint be substantiated by administrative standards before awarding good time credit could be used to guard against false reports motivated by a desire to obtain an early release from prison. Moreover, as time goes by, if prosecutors and prison officials work together to consistently remove offenders from the prison population, fears about stepping forward may wane.

"Victimless" prosecutions may also be more expensive in that without a testifying witness, various experts may be necessary. For example, in some jurisdictions an expert may be able to testify that the victim suffered from rape trauma syndrome. Such experts would have to be paid from the prosecutor's budget or other public funds. The Prison Rape Elimination Act has set aside monies that could be used for such purposes (see PREA, 2003 sections 15604 and 15605).

In any event, it is clear that these cases can be made to a much greater extent than is currently happening if prosecutors would be willing to make such prosecutions a priority. As with domestic violence 20 years ago, there is an emerging consensus, as evidenced by recent legislative action such as the Prison Rape Elimination Act, that prison rape is a serious problem worthy of societal attention and resources. Prosecutors' offices should respond with vigorous polices that assure such offenses are no longer ignored.

Once an inmate is convicted of a sex offense against another prisoner, s/he should never again be allowed into the general population. Currently, "in the rare occasions when prison rapists receive some form of institutional discipline, such as lock-up in "the hole," inmates are usually released back to the general prison population once their term of special punishment expires" (Mann \& Cronan, 2001-2002, p. 181). Such a scenario makes retaliation very likely. But, even if the victim could be adequately protected by removing him or her from the prison, the evidence suggests that perpetrators tend to victimize multiple people (see Donaldson, 2001; Hensley, Dumond, Tewksbury \& Dumond 2002; O’Donnell, 2004). It is, therefore, imperative that prisons operate on the assumption that perpetrators present a continuing threat and that all identified offenders are housed in single cells without any contact with other prisoners for the remainder of their time behind bars.

Correctional facilities also need to make sure that they have protocols in place to assure that their investigation will facilitate rather than thwart prosecution. A thorough and timely investigation of all complaints needs to be made. Corrections officers and medical staff need to be trained to assure that they can consistently and competently perform important tasks including collecting physical evidence, interviewing victims and witnesses, and interrogating suspects. Now that federal funds are available to support such training, even poor state prison systems can get the necessary training (see PREA, 2003 sections 15604 and 15605).

Finally, prisons need to devise inmate educational programs. Anecdotal evidence 
suggests that informing a would-be rapist that the rape may result in his infection with HIV or other communicable disease has prevented some rapes in prison (Peek, 2004). Requiring all prisoners to receive basic education about the health risks associated with unprotected sexual contact generally, and sexual assaults, specifically, thus may be useful in deterring some potential rapists.

In addition, it is clear from the research that prison sexual assaults are not random occurrences. Prisoners who are young and/or recently admitted are more at risk of victimization than older and more experienced prisoners (Dumond, 1992; Hensley et al., 2003). Youthful, inexperienced prisoners frequently encounter problems when they accept a loan or a favor from a sexually aggressive inmate who later seeks repayment in the form of sex (Peek, 2004). Educating new prisoners that accepting loans or favors, even from those who approach in a seemingly friendly manner, may place them at risk for assault as might other deviations from the "prison code." For example, evidence suggests being too talkative in an effort to fit in, appearing anxious or afraid and exhibiting other stereotypically "feminine" behaviors increase an inmates' chances of victimization (Hensley et al., 2003; Human Rights Watch, 2001). Having such information may allow some potential victims to modify their behavior in ways that may protect them from sexual assault.

Sadly, some of the attributes which correlate with victimization are immutable characteristics that are not easily modified or concealed. For example, some evidence suggests that inmates who are white, with light builds and convicted of non-violent offenses are more likely to be victimized (Dumond, 1992; Hensley et al., 2003). Homosexuals and bisexuals are also disproportionately targeted by sexual aggressors (Hensley et al., 2003) as are transgender inmates (Peek, 2004). For such inmates, notification of their rights and available options, such as the right to be housed in an administrative segregation unit may be helpful in reducing their victimization in the short run. Obviously, such an approach smacks of victim-blaming (Peek,
2004), but absent a major shift in prison culture, they may be a potential victims best hope.

These recommendations are consistent with the recommendations made by Human Rights Watch (2001) which called for an orientation program for incoming male prisoners educating them about the issue of prisoner-on-prisoner sexual abuse, emphasizing their right not to be abused, how to report abuse and preserve evidence if an assault should occur, how to avoid scenarios commonly associated with abuse, and access options such as protective custody. Further refinements in identifying specific prisoner groups who should receive special education should be relatively easy now that the Prison Rape Elimination Act requires the Bureau of Justice Statistics to annually review data on the incidence of prison rape to identify common characteristic of both victims and perpetrators. The availability of such data will allow administrators to stay abreast of emerging victimization and perpetration trends and then modify their educational programs appropriately to most affectively reach at risk prisoners

\section{Conclusion}

Sexual assault in prison presents a serious health risk to incarcerated men and women. Such assaults not only present occasions for the transmission of deadly and debilitating diseases but they can also result in serious physical injuries. In addition to physical injury and disease, victims suffer mental and emotional damage. When victimized inmates are released - as almost all of them eventually are -- they can bring serious communicable diseases into the community including HIV/AIDS, syphilis, and hepatitis. They also come to the community brutalized and angry, and in some cases, the racial character of the assaults they endured has left them bigoted as well. The community then faces the triple threat of disease, further criminal violence and increased racism.

After decades of inaction, efforts to confront the problem of prison rape and protect victims and communities from the devastating effects of this type of violence have been undertaken. Legislative efforts such as the Prison Rape 
Elimination Act are promising but more needs to be done. Prosecutors and prison administrators need to work together to develop new strategies for dealing with prison rapists that effectively punish perpetrators, protect victims, and assure that perpetrators will be prevented from victimizing others.

\section{References}

Abraham, S. (2001). Male rape in U.S. prisons: Cruel and unusual punishment. Human Rights Brief, 1, 510.

Alarid, L. F. (2000). Sexual assault and coercion among incarcerated women prisoners: Excerpts from prison letters. The Prison Journal, 80, 391-406.

Anonymous. (2001). The story of a black punk. In D. Sabo, T. Kupers, \& W. London (Eds.), Prison masculinities (pp. 127-132). Philadelphia: Temple University Press.

Ashkin, D., Malecki, J., \& Thomas, D. (2005). Tuberculosis outbreak among staff in correctional facilities, Florida, 2001-2004: lessons re-learned. Infectious Diseases in Corrections Report, 8, 15.

Bell, C., Coven, M., Cronan, J., Garza, C., Guggermos, J., \& Storto, L. (1999). Rape and sexual misconduct in the prison system: Analyzing America’s most “open secret.” Yale Law \& Policy Review, 18, 195-220.

Bureau of Justice Statistics. (2004). Data collection for the prison rape elimination act of 2003. Bureau of Justice Statistics Status Report, (June 30). Washington, DC: U.S. Department of Justice, Office of Justice Programs.

Calhoun, A. J., \& Coleman, H. D. (2002). Female inmates perspectives on sexual abuse by correctional personnel: An exploratory study. Women \& Criminal Justice, 13, 101-124.

Catalano, S. M. (2004). Criminal victimization, 2003. Bureau of Justice Statistics National Crime Victimization Survey, (September). Washington DC: U.S. Department of Justice, Office of Justice Programs.

Chesney-Lind, M., \& Pollock, J. M. (1995). Women’s prisons: equality with a vengeance. In A.V. Merlo \& J.M. Pollack (Eds.), “Women, law \& social control.” (pp. 155-175). Boston: Allyn \& Bacon.

Cooper, T. (2004). Rape case against prison guard dropped. Omaha World-Herald (Sept. 18), 04B.

Day, A. (1998). Cruel and unusual punishment of female inmates: The need for redress under 42 U.S.C. 1983. Santa Clara Law Review, 33, 555-587.

Dobash, R. P., Dobash, R. E., \& Gutteridge, S. (1986). The imprisonment of women. New York: Basil and Blackwell.

Donaldson, S. (2001). A million jockers, punks and queens. In D. Sabo, T. Kupers \& W. London (Eds.), Prison masculinities (pp. 118-126). Philadelphia: Temple University Press.

Dumond, R. (1992). The sexual assault of male inmates in incarcerated settings. International Journal of Sociology of Law, 20, 135-157.

Dumond, R., \& Dumond, D. (2002). The treatment of sexual assault victim. In C. Hensley (Ed.), "Prison sex: Practice \& policy.” (pp. 67-87). Boulder, CO: Lynne Rienner Publishers, Inc.

Easteal, P. (2001). Women in Australian prisons: The cycle of abuse and dysfunctional environments. The Prison Journal, 81, 87-112.

Eigenberg, H. (2000). Correctional officers and their perceptions of homosexuality, rape and prostitution in male prisons. The Prison Journal, 80, 415-433.

Federal Bureau of Investigation (2005). Uniform crime report. Washington, DC: Author.

Gilligan, J. (2000). Violence: Reflections on our deadliest epidemic. London: Jessica Kingsley.

Goldstein, A. (2003). High rates of infection found in Maryland prisons. The Washington Post (May 7): B07.

Harrison, P. M., \& Beck, A. J. (2004). Prisoners in 2003. Bureau of Justice Statistics Bulletin. Washington, DC: U.S. Department of Justice, Office of Justice Programs. 
Hensley, C., Dumond, R., Tewksbury, R., \& Dumond, D. (2002). Possible solutions for preventing inmate sexual assaults: Examining wardens’ beliefs. American Journal of Criminal Justice. 27, 19-32.

Hensley, C., Koscheski, M., \& Tewksbury, R. (2003). The impact of institutional factors on officially reported sexual assaults in prisons. Sexuality and Culture, 7, 16-26.

Hensley, C., Tewksbury, R., \& Castle, T. (2003). Characteristics of prison sexual assault targets in male Oklahoma correctional facilities. Journal of Interpersonal Violence, 18, 595-606.

Human Rights Watch (2001). No escape: male rape in U.S. prisons. Retrieved May 6, 2005, from http://www.hrw.org/reports/2001/prison/report.html

Kilpatrick D. G., Edmunds C.N., \& Seymour A.K. (1992). Rape in America: A report to the nation. Arlington, VA: National Victim Center and Medical University of South Carolina.

Knowles, G. J. (1999). Male prison rape: a search for causation and prevention. The Howard Journal, 38, 267-282.

Kupers, T. (2001). Rape and the prison code. In D. Sabo, T. Kupers \& W. London (Eds.), Prison masculinities (pp. 111-117). Philadelphia: Temple University Press.

Latour, F. (2001). Sheriff's guard suspended after inmate's sexual contact. The Boston Globe (July 11), B5.

Lockwood, D. (1980). Prison sexual violence. New York: Elsevier.

Mann, C. D., \& Cronan, J. P. (2001-2002). Forecasting sexual abuse in prison: The prison subculture of masculinity as a backdrop for deliberate indifference. Journal of Criminal Law and Criminology, 92, 127-185.

Messerschmidt, J. W. (2001). Masculinities, crime and prison. In D. Sabo, T. Kupers \& W. London (Eds.), Prison masculinities (pp. 67- 72). Philadelphia: Temple University Press.

McGuire, M. D. (2005). Violence as a routine feature of prison life for women: A qualitative assessment. Forthcoming in Corrections Compendium.

Meyer, M. (1992). Coercing sex behind bars. Newsweek 120 (November 9), 76-78.

O’Donnell, I. (2004). Prison rape in context. British Journal of Criminology, 44, 241-255.

Peek, C. (2004). Breaking out of the prison hierarchy: transgender prisoners, rape, and the eighth amendment. Santa Clara Law Review, 44, 1211-1248.

Pino, N., \& Meier, R. (1999). Gender differences in rape reporting. Sex Roles, 40, 979-990.

Polych, C., \& Sabo, D. (2001). Sentence - death by lethal injection: IV-drug use and infectious disease transmission in North American prisons. In D. Sabo, T. Kupers \& W. London (Eds.), Prison masculinities (pp. 173-183). Philadelphia: Temple University Press.

Robertson, J. E. (2003). Rape among incarcerated men: Sex, coercion and STDs. AIDs Patient Care and STDs, 17, 423-30.

Rohde, D. (2001). A health danger from a needle becomes a scourge behind bars. The New York Times (August 6), 1.

Sagarin, E. (1976). Prison homosexuality and its effects on post-prison sexual behavior. Psychiatry, 39, 245-257.

Saum, C., Surratt, H., Inciardi, J., \& Bennett, R. (1995). Sex in prison: exploring the myths and realities. The Prison Journal, 75, 413-430.

Smith, B. V. (2001). Sexual abuse against women in prison. Criminal Justice Magazine, 16, 30- 37.

Springfield, D. (2000). Sisters in misery: utilizing international law to protect United States female prisoners from sexual abuse. Indiana International \& Comparative Law Review, 10, 457.

Struckman-Johnson, C., \& Struckman-Johnson, D. (2002). Sexual coercion reported by women in three Midwestern prisons. Journal of Sex Research, 39, 217-228.

Struckman-Johnson, C., \& Struckman-Johnson, D. (2000). Sexual coercion rates in seven Midwestern prison facilities for men. The Prison Journal, 80, 379-390.

Struckman-Johnson, C., Struckman-Johnson, D., Rucker, L., Bumby, K., \& Donaldson, S. (1996). Sexual coercion reported by men and women in prison. Journal of Sex Research, 33, 67-76. 
Travis, J. (2005). Prisoner reentry: The iron law of imprisonment. In R. Muraskin (Ed.), Key correctional issues (pp. 64-73). Upper Saddle River, NJ: Pearson.

Vetstein, R. (1997). Rape and aids in prison: On a collision course to a new death penalty. Suffolk Law Review, 30, 863-904.

\section{Case Cited}

Carrigan v Davis, 70 F. Supp. 2d 448 (D. Del. 1999)

Author Information

M. Dyan McGuire, J.D., Ph.D.

Assistant Professor

St. Louis University

E-Mail: mcguirem@slu.edu 